\title{
Hepatoprotective effect of water soluble extract of Coleus barbatus on cholestasis on young rats ${ }^{1}$
}

\author{
Efeito hepatoprotetor do extrato aquoso de Coleus barbatus na colestase em ratos jovens
}

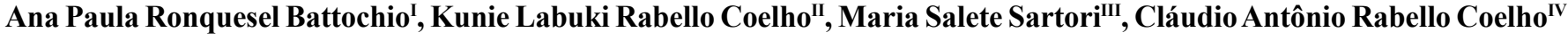

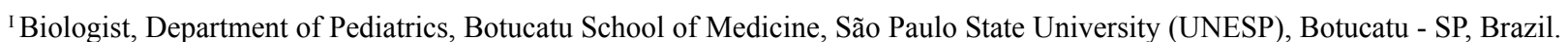 \\ II PhD, Assistant Professor, Head of the Division of Hepatic Histopathology, Department of Pathology, UNESP, Botucatu - SP, Brazil. \\ III Biologist, Postgraduate Fellow in Physiopathology, Head of the Biochemical Unit Clinical Analysis Laboratory, UNESP, Botucatu - SP, \\ Brazil. \\ Iv PhD, Assistant Professor, Head of the Division of Pediatric Hepatology, Department of Pediatrics, UNESP, Botucatu - SP, Brazil
}

\begin{abstract}
Purpose: To test the effects of water extract of Coleus barbatus (WEB) on liver damage in biliary obstruction in young rats. Methods: Forty 21 day-old male Wistar rats were divided into four groups of ten 21 day old (P21) submitted to sham or actual operation (S or L) combined with WEB or Water (B or A). At P48 pentobarbital sleeping time (ST) was measured. At P49 they were submitted to euthanasia to determine of serum activities of aspartate aminotransferase (AST) and alanine aminotransferase (ALT), liver wet weight (PFF) and, on hepatic histological slides, the frequency of mitoses (FM), the number of necrotic areas (NN), intensity of fibrosis (IF) and intensity of ductal proliferation (IPD). Two Way ANOVA, the S.N.K. test and the Wilcoxon test for paired multiple comparisons were employed to study the effects of cholestasis and those of EAB and their interactions. The Pearson's coefficient of linear correlation of between paired histological variables separately for the groups LA and LD was determined. The test results were considered statistically significant when the $\mathrm{p}$ of $\alpha$ error $<0.05$. Results: Cholestasis increased the TS, ALT, AST, PFF, MI, NN, IF and IPD. The EAB decreased the TS and IM in the animals without cholestasis (sham operated animals). The EAB decreased the TS, ALT, AST, PFF, MI, NN and IF of the cholestatic animals. In the LA group there was a positive correlation between the IPD and the IF, a negative correlation between the IPD and the FM and a negative correlation between the IF and the FM. In the LD group there was a negative correlation between the NN and the IPD. Conclusions: In the absence of cholestasis the EAB reduces the pentobarbital sleeping time and decreases the frequency of mitoses. The EAB has a hepatoprotective effect on the biliary cirrhosis secondary to extra-hepatic biliary obstruction.

Key words: Cholestasis, Extrahepatic. Liver Cirrhosis, Biliary. Liver Cirrhosis, Experimental. Rats.
\end{abstract}

\section{RESUMO}

Objetivo: Testar os efeitos do extrato aquoso de Coleus barbatus (EAB) na cirrose biliar secundária por obstrução das vias biliares extra-hepáticas em ratos jovens. Métodos: Quarenta ratos Wistar machos com 21 dias de vida (P21), foram distribuídos em quatro grupos de 10 animais, submetidos a operação simulada ou dupla ligadura e ressecção do ducto biliar (S ou L) combinados EAB e a Água (B ou A). No P48, foi medido o tempo de sono com o pentobarbital (TS). No P49, foram submetidos a eutanásia para a determinação das atividades séricas do aspartato aminotransferase (AST) e da alanina aminotransferases (ALT); após a eutanásia foram avaliados o peso fresco do fígado (PFF) e, em cortes histológicos do fígado, a freqüência de mitoses (FM), o número de áreas de necrose (NN), a intensidade da fibrose (IF) e da proliferação ductal (IPD). Os efeitos da colestase, os do EAB e suas interações foram testados pela ANOVA com dois fatores, e as comparações múltiplas pareadas foram realizadas pelo teste de S.N.K ou teste de Wilcoxon. Também foi determinada a correlação linear de Pearson entre as variáveis histológicas duas a duas separadamente para os grupos LA e LD. O nível de significância estatística para os vários testes foi de $\mathrm{p}$ do erro $\alpha<0,05$. Resultados: A colestase aumentou significativamente o TS, a ALT, a AST, o PFF, a MI, o NN, a IF e a IPD. O EAB diminuiu o TS e a IM nos animais sem colestase (operação simulada). O EAB diminuiu o TS, a ALT, a AST, o PFF, a MI, o NN e IF na colestase. No grupo LA houve correlação positiva entre a IPD e a IF, correlação negativa entre a IPD e a FM e correlação negativa entre a IF a FM. No grupo LD houve correlação negativa entre o NN e a IPD. Conclusões: Na ausência de colestase o EAB encurta o tempo de sono e diminui a freqüência de mitoses. O EAB apresenta efeito hepatoprotetor no modelo de cirrose biliar secundária a obstrução biliar extra-hepática.

Descritores: Colestase Extra-Hepática. Cirrose Hepática Biliar. Cirrose Hepática Experimental. Ratos.

1. Research performed at the Infant Hepathology Division, Department of Pediatrics, School of Medicine of Botucatu, São Paulo State University (UNESP), Botucatu - SP, Brazil. 


\section{Introduction}

The main indication for liver transplantation in infants and children is biliary atresia, a severe cause of hepatobiliary disease which presents a mortality rate of $100 \%$ when untreated ${ }^{1,2}$.

Ligature and resection of the common bile duct in young rats has been used as a model for obstructive cholestasis and the consequent secondary biliary cirrhosis in infants ${ }^{3}$.

Coleus barbatus from the Lamiaceae family ${ }^{4}$, commonly known as National Boldo, Brazilian Boldo or False Boldo is used in popular Brazilian medicine in the treatment of liver problems $^{5,6}$. However, there are no reports in the literature of experimental or clinical studies on the effects of Coleus barbatus on cholestasis or other hepatic diseases. A few plants extracts have been tested in bile duct ligated adults rats: Salvia miltiorrhiza ${ }^{7}$; Camellia $^{8}$ and Stephania tetrandra ${ }^{9}$.

Our aim was to test possible hepatoprotective effects of a water extract of Coleus barbatus in the model of obstructive cholestasis. To that effect we studied in four groups of young rats (bile duct ligated plus WEB or water and cham operated plus WEB or water) the following variables to ascertain the extent of liver disfunction and damage.

Pentobarbital sleeping time is a easily performed liver function test in rats ${ }^{10}$ which evaluates the oxidative metabolism of drugs, which is impaired in chronic cholestatic disease that reduces the activity of enzyme cytochrome $\mathrm{P} 450^{11}$. Pentobarbital sleeping time was used in several studies to demonstrate hepatoprotective effects of plant extracts (Calotropis procera ${ }^{12}$, Artemisia scoparia $^{13}$, Cyperus scariosus ${ }^{14}$ and Bougainvillea spectabillis ${ }^{15}$ ).

The serum aminotransferase activities (alanine aminotransferase - AST and aspartate aminotransferase - ALT) are biochemical markers of the rate of hepatocelular lesions ${ }^{16}$. In experimental cholestasis, through ligature and common bile resection, a significant increase in these cellular enzymes occurs ${ }^{16}$. Fujii, $19977^{17}$ summarized the toxicological correlation between serum biochemical tests and the hepatic histopathology found in his own experiments and those published by other authors, with rats and dogs, and concluded the increase in ALT and AST presents a correlation with the intensity of necrosis.

Hepatic histopathology in laminas of the liver with cholestasis showed the intensity of the following lesions ${ }^{18,19}$ : a) hepatocyte coagulation necrosis ${ }^{20}$; b) fibrosis ${ }^{21}$; c) ductal proliferation ${ }^{22}$. The regeneration of liver cells can be observed by the presence of mitosis ${ }^{23}$.

\section{Methods}

Collection and preparation of the water-soluble extract of Boldo (WEB)

The plant (Coleus barbatus) was collected fresh, in its natural habitat, in the district of Rubião Jr., Botucatu, during February 2000. It was identified and registered under the number BTU24169, in the Herbarium of the Botanical Department of the Biosciences Institute, UNESP - São Paulo State University, Botucatu, São Paulo. The leaves were oven-dried at $60^{\circ} \mathrm{C}$ for three days and then grounded with a pestle until they constituted a fine powder. This was stored in hermetically sealed plastic flasks and labeled. The water-soluble extract was prepared by passing one liter of water at room temperature through a funnel with $60 \mathrm{~g}$ of the powder placed in filter paper. The filtrate was stored in $10 \mathrm{ml}$ amber colored glass flasks, conserved in a freezer at $-20^{\circ} \mathrm{C}$ for up to eight weeks, while thawed aliquots were maintained in a refrigerator at $-4^{\circ} \mathrm{C}$ for use in a maximum of a two day period.

Forty male Wistar rats were studied, born in the Pediatrics Experimental Laboratory of the Botucatu Faculty of Medicine - UNESP, of nulliparous females, weighing 180 to $220 \mathrm{~g}$ at the onset of gestation, provided by the Bioterio Central of the Botucatu Campus - UNESP. From birth they were suckled in groups of six animals per dam until the $21^{\text {st }}$ day of life (P21). During this period and for the whole experimental period (P21 to $\mathrm{P} 49$ ), the animals were maintained under controlled environmental conditions - temperature between 22 to $23^{\circ} \mathrm{C}$ and a 12 hour light/dark cycle.

\section{Experimental procedure}

The experimental procedure was approved by the Ethics Commission in Animal Experimentation of the Botucatu Faculty of Medicine / UNESP - São Paulo State University, protocol number 64, 25/10/1999, in accordance with the Principles of Ethics in Animal Experimentation of the Brazilian College of Animal Experimentation (COBEA) ${ }^{24}$. The maintenance of the animals and anesthetic, surgical and euthanasia procedures were performed according to the recommendations of the Canadian Council of Animal Care (1984) ${ }^{25}$.

On P21, each animal was randomly assigned to one of the four experimental groups of 10 animals each:

SA Group: sham operation with daily administration, by gavage, of $5 \mu 1$ of water per gram of animal weight, SB Group: sham operation with daily administration, by gavage, of $5 \mu \mathrm{l}$ of water-soluble extract of Boldo (WEB) per gram of animal weight, LA Group: double ligature and resection of the common bile duct with daily administration, by gavage, of $5 \mu 1$ of water per gram of animal weight, LB Group: double ligature and resection of the common bile duct with daily administration, by gavage, of $5 \mu \mathrm{l}$ of WEB per gram of animal weight.

All animals had ad libitum access to water and standard feed with $18 \mathrm{~g}$ of protein per $100 \mathrm{~g}$ of feed prepared by the Pediatrics Experimental Laboratory of the Botucatu School of Medicine of the São Paulo State University-UNESP (Table 1). 
TABLE 1 - Feed composition (18g/100g of proteins) prepared by the Pediatrics Department Experimental Laboratory

\begin{tabular}{|c|c|}
\hline DIETARY COMPONENTS & g/kg \\
\hline Protein (casein) & 1.8 \\
\hline Saline Mixture ${ }^{26,27}$ & 0.4 \\
\hline Fiber (corncob) & 0.4 \\
\hline Vitamin Mixture $^{18}$ & 0.1 \\
\hline Sodium Benzoate & 0.01 \\
\hline Corn Oil & 0.8 \\
\hline Sucrose & 1.0 \\
\hline Cornstarch (Maizena ${ }^{\circledR}$ ) & 5.49 \\
\hline
\end{tabular}

The ligature and resection of the common bile duct was performed according to the technique presented by Cameron and Oakley ${ }^{28}$ with modifications ${ }^{29}$.

The sham operation followed exactly the same technique described above with exception of the ligatures and common bile duct resection.

\section{Sleeping time by pentobarbital}

On P48, the sleeping time test was performed using pentobarbital. The animals received pentobarbital (concentration of $3 \mathrm{~g} / 100 \mathrm{ml}$ of solution) through intraperitoneal injection at a dosage of $50 \mathrm{mg} / \mathrm{kg}$ of rat body weight (or $0.0017 \mathrm{ml} / \mathrm{g}$ of animal weight) and time was measured in minutes, from the loss of position reflex to its recuperation.

Euthanasia was performed on P49, beginning with an intraperitoneal injection of sodium pentobarbital, followed by posterior bleeding. The blood and liver were collected for biochemical tests:

- aminotransferase dosage: ALT (alanine aminotransferase) and AST (aspartate aminotransferase) in IU/L by the automated colorimetric enzymatic method using Technicon ${ }^{\circledR}$ equipment, model RAXT;

- Liver wet weight in $\mathrm{g}$ using Mettler Toledo digital scales - model PB 3002, maximum weight $=3.100 \mathrm{~g}$, minimum weight $=0.5 \mathrm{~g}$, sensibility $0.1 \mathrm{~g}$.

\section{Histological lesions}

A fragment of the right lobe of the liver, 0.3 to 0.35 $\mathrm{cm}$ thick, was removed from each animal. Histological sections of a around $4 \mu \mathrm{m}$ thick were stained with hematoxylin and eosin stains. A semi-quantative analysis of a slide from each animal was performed and scores from zero to three for the intensity of fibrosis and ductal proliferation were attributed to each animal. Areas of necrosis were counted in the whole slide, and the number of mitosis in ten fields at high magnification were counted. Three independent measurements of each of the histopathological variables mentioned above were performed.

\section{Statistical procedures}

The mean and standard deviation or median values of each variable for each group were calculated. The results of each variable for each experimental group were compared according to the following steps:

1) testing for normality and equality of variances of the values obtained for each group;

2) if the data passed these tests, a two way analysis of variance was applied, where one factor was the administration or non-administration of WEB and the other the presence (double ligature and common bile duct resection) or absence of cholestasis (sham operation). The effects of each factor were tested independently of the effect of the other, as well as the interaction between both factors;

3) when a significant interaction between factors was found $(\mathrm{p} \leq 0.05)$, multiple paired comparisons were performed using the Student-Newman-Keuls (S.N.K.) method, identifying pairs of groups with significant differences among them ( $p$ of $\alpha \leq 0.05$ );

4) if the measurements did not satisfy the criteria of item 1, mathematical transformations were performed and the transformed values that passed the tests where employed in the calculations as in item 2 above. Pentobarbital sleeping time and aminotransferase were substituted by their rank number.

5) histological variables (frequency of mitosis, number of areas of necrosis and intensity of ductal proliferation) were analysed by means of a factorial delineation using a generalized linear model, presuming a Poisson's distribution and a canonic (logarithmic) connection. A 1/6 value was added to the observations for a better fit to the model. For this analysis the means of the 30 readings of each group were used, $n=30$ (3 readings per animal from each experimental group). However this model did not result in an adequate fit: in the case of the number of mitosis excessive dispersion occurred and in the case of the variables number of areas of necrosis, intensity of fibrosis and the intensity of ductal proliferation a sub-dispersion occurred. Even when the interaction was not significant, we opted to perform the decomposition of the effects of the drug and ligature factors in the nestling effect which were tested using the Wilcoxon test $(\mathrm{p}<0.05)$.

Pearson's analysis of linear correlation was applied to paired histological variables ( $\mathrm{p}$ of $\alpha<0,05$ ) separately for groups LA and LB.. For this analysis the means of the 3 measurements per animal from each experimental group $(n=10)$ were used.

Table 2 shows the mean and standard deviation values of the variables for which no mathematical transformations were necessary and the median of those values for which transformations were necessary. The graphs in figures 1 and 2 show the means (solid points), the standard deviations above and below the mean (lines) and the individual values (hollow points) of the measurements, or their transformations, performed on each experimental group.

Calculations were performed by the Sigma Stat program for Windows ${ }^{\odot}$ 2.0, Jandel Corporation or the SAS program. 


\section{Results}

Sleeping time with pentobarbital (ST), aminotransferase serum activities (AST and ALT) and liver wet weight $(L W W)$

Cholestasis caused a statistically significant prolongation in $\mathbf{S T}$ in animals which received WEB (medians: $(\mathrm{LB}=172.80 \mathrm{~min})>.(\mathrm{SB}=97.30 \mathrm{~min})$.$) and in those which did$ not receive WEB (medians: $(\mathrm{LA}=374.30 \mathrm{~min}$. $)>(\mathrm{SA}=111.30$ min.)). The prolongation of the $\mathbf{S T}$ was decreased by WEB in the animals with cholestasis (Medians: $(\mathrm{LB}=172.80$ $\min .)<(\mathrm{LA}=374.30 \mathrm{~min}$. $)$ ). The same effect was seen in animals without cholestasis (medians: $(\mathrm{SB}=97.30$ $\min .)<(\mathrm{SA}=111.30 \mathrm{~min})$.$) , Figure 1 \mathrm{~A}$ and Table 2 .

Cholestasis caused a statistically significant increase in ALT in animals which received WEB (medians: ( $\mathrm{LB}=105.50$ $\mathrm{IU} / \mathrm{L})>(\mathrm{SB}=38.00 \mathrm{IU} / \mathrm{L}))$ and those which $\operatorname{did}$ not receive WEB (medians: $(\mathrm{LA}=150.00 \mathrm{IU} / \mathrm{L})>(\mathrm{SA}=37.00 \mathrm{IU} / \mathrm{L}))$. The increase in ALT caused by cholestasis was decreased by the administration of WEB (medians: $(\mathrm{LB}=105.50 \mathrm{IU} / \mathrm{L})<(\mathrm{LA}=150.00 \mathrm{IU} /$ L)) (Figure 1B and Table 2).

Cholestasis also caused a statistically significant increase in AST in the animals which received WEB (medians: $(\mathrm{LB}=25.50 \mathrm{IU} / \mathrm{L})>(\mathrm{SB}=12.00 \mathrm{IU} / \mathrm{L}))$ and in those which $\mathrm{did}$ not received WEB (medians: $(\mathrm{LA}=34.00 \mathrm{IU} / \mathrm{L})>(\mathrm{SA}=10.50 \mathrm{IU} /$ L)). The increase in AST caused by cholestasis was decreased by the administration of WEB (medians: ( $\mathrm{LB}=25.50 \mathrm{IU} /$ $\mathrm{L})<(\mathrm{LA}=34.00 \mathrm{IU} / \mathrm{L})$ ) (Figure $1 \mathrm{C}$ and Table 2).

Cholestasis caused a statistically significant increase in $\mathbf{L W W}$ in animals which received WEB (means: $(\mathrm{LB}=7.22$ $\mathrm{g})<(\mathrm{SB}=9.71 \mathrm{~g}))$ and in those which did not received WEB (means: $(\mathrm{LA}=17.68 \mathrm{~g})>(\mathrm{SA}=10.74 \mathrm{~g})$ ). The increase of $\mathbf{L W W}$ caused by cholestasis was decreased by WEB ((means: $(\mathrm{LB}=7.22)<(\mathrm{LA}=17.68)$ ) (Figure 1D and Table 2).

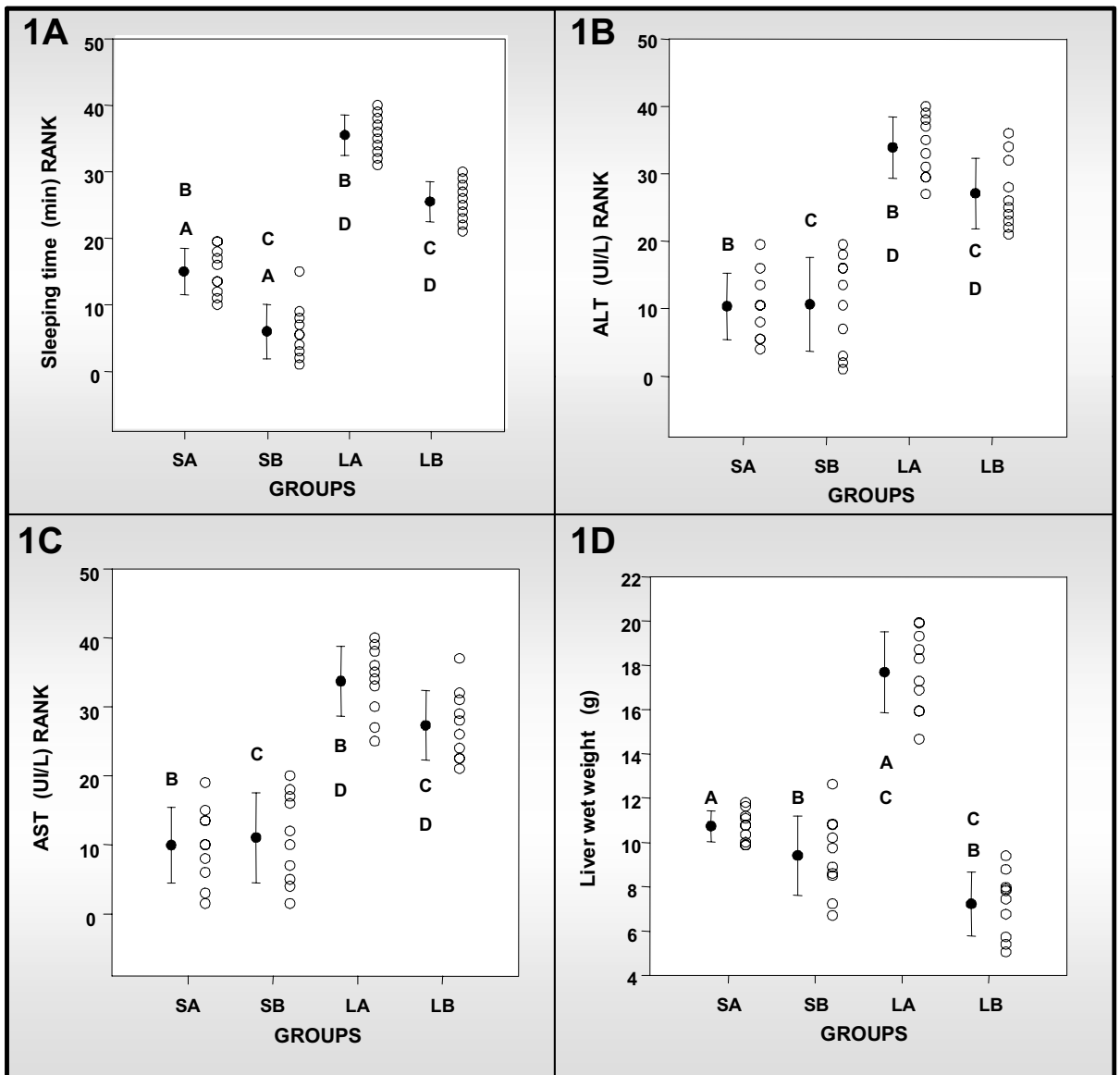

FIGURE 1 - Means, standard deviations and individual values of sleeping time (min.) (1A) of aminotransferase serum activity ALT (IU/L) (1B), aminotransferase serum activity AST (IU/L) (1C), and liver wet weight (g) (1D) in rats, in groups of 10, submitted to one of the following treatments: SA: sham operation with daily administration of water; SB: sham operation with daily administration of WEB; LA: double ligature with common bile duct resection with daily administration of water; LB: double ligature with common bile duct resection with daily administration of WEB. Letters repeated in figures $1 \mathrm{~A}, 1 \mathrm{~B}, 1 \mathrm{C}$ and $1 \mathrm{D}$, of the graphs, indicate the group pairs with significant differences among them in the S.N.K. test $(p<0.05)$ : $\mathbf{A}=\mathrm{SA}>\mathrm{SB} ; \mathbf{B}=\mathrm{LA}>\mathrm{SA}$; $\mathbf{C}=\mathrm{LB}>\mathrm{SB} ; \mathbf{D}=\mathrm{LA}>\mathrm{LB}$. 
TABLE 2 - Sleeping time, aminotransferase serum activities (ALT and AST) and liver wet weight in young rats comparisons between effects of cholestasis and of WEB, interaction between these effects and descriptive analysis

\begin{tabular}{|c|c|c|c|c|}
\hline Variables & Procedure $^{A}$ & Drug $^{B}$ & $\begin{array}{l}\text { Interaction e } \\
\text { Comparison }^{c} \\
\end{array}$ & $\begin{array}{c}\text { Descriptive } \\
\text { Analysis }^{\mathrm{D}} \\
\end{array}$ \\
\hline $\begin{array}{l}\text { Sleeping } \\
\text { Time } \\
\text { (min.) }\end{array}$ & $\begin{array}{c}(\mathrm{LA}+\mathrm{LB})>(\mathrm{SA}+\mathrm{SB}) \\
\mathrm{p} \leq 0.001 \\
\text { significant }\end{array}$ & $\begin{array}{c}(S A+L A)>(S B+L B) \\
p \leq 0.001 \\
\text { Significant }\end{array}$ & $\begin{array}{c}p \leq 0.001 \\
\text { significant } \\
L A>\text { LB } p<0.05 s . \\
\text { LA }>\text { SA } p<0.05 s . \\
\text { LB }>\text { SB } p<0.05 s . \\
\text { SA }>\text { SB } p<0.05 \\
\text { s. }\end{array}$ & $\begin{array}{r}\text { Medians } \\
\text { SA }=111.30 \\
\text { SB }=97.30 \\
\text { LA }=374.30 \\
\text { LB }=172.80\end{array}$ \\
\hline $\begin{array}{c}\text { ALT } \\
\text { (IU/L) }\end{array}$ & $\begin{array}{c}(\mathrm{LA}+\mathrm{LB})>(\mathrm{SA}+\mathrm{SB}) \\
\mathrm{p} \leq 0.001 \\
\text { significant }\end{array}$ & $\begin{array}{c}(S A+L A) \approx(S B+L B) \\
p=0.070 \\
\text { not significant }\end{array}$ & $\begin{array}{c}p=0.049 \\
\text { significant } \\
L A>L B p<0.05 s . \\
L A>S A p<0.05 s . \\
L B>S B p<0.05 s . \\
S A \approx S B p=0.249 \\
\text { n.s. }\end{array}$ & $\begin{array}{l}\text { Medians } \\
\text { SA }=37.00 \\
\text { SB }=38.00 \\
\text { LA }=150.00 \\
\text { LB }=102.50\end{array}$ \\
\hline $\begin{array}{l}\text { AST } \\
\text { (IU/L) }\end{array}$ & $\begin{array}{c}(\mathrm{LA}+\mathrm{LB})>(\mathrm{SA}+\mathrm{SB}) \\
\mathrm{p} \leq 0.001 \\
\text { significant }\end{array}$ & $\begin{array}{c}(S A+L A) \approx(S B+L B) \\
p=0.141 \\
\text { not significant }\end{array}$ & $\begin{array}{c}p=0.040 \\
\text { significant } \\
L A>L B p<0.05 \mathrm{~s} . \\
L A>S A p<0.05 \mathrm{~s} . \\
L B>S B p<0.05 \mathrm{~s} . \\
S A \approx S B p=0.249 \\
\text { n.s. }\end{array}$ & $\begin{array}{l}\text { Medians } \\
\text { SA }=10.50 \\
S B=12.00 \\
L A=34.00 \\
\text { LB }=25.50\end{array}$ \\
\hline $\begin{array}{l}\text { Liver wet } \\
\text { weight } \\
\text { (g) }\end{array}$ & $\begin{array}{c}(\mathrm{LA}+\mathrm{LB})>(\mathrm{SA}+\mathrm{SB}) \\
\mathrm{p} \leq 0.001 \\
\text { significant }\end{array}$ & $\begin{array}{c}(S A+L A)>(S B+L B) \\
p \leq 0.001 \\
\text { significant }\end{array}$ & $\begin{array}{c}p \leq 0.001 \\
\text { significant } \\
L A>L B p<0.05 \mathrm{~s} . \\
L A>S A p<0.05 \mathrm{~s} . \\
L B<S B p<0.05 \mathrm{~s} . \\
S A \approx S B p<0.05 \\
\text { n.s. }\end{array}$ & $\begin{array}{l}\text { Means } \pm \text { DP } \\
\text { SA }=10.74 \pm 0.70 \\
\text { SB }=9.41 \pm 1.79 \\
\text { LA }=17.68 \pm 1.83 \\
\text { LB }=7.22 \pm 1.45\end{array}$ \\
\hline
\end{tabular}

\section{Histological lesions}

Cholestasis, with no administration of WEB, caused a statistically significant increase in FM (Means: $(\mathrm{LA}=14.13)>(\mathrm{SA}=11.00))$. WEB significantly reduced $\mathbf{F M}$ in animals without cholestasis (Means: $(\mathrm{SB}=3.53)<(\mathrm{SA}=11.00)$ ). WEB administration in animals with cholestasis reduced FM levels to those observed in animals without cholestasis and which received WEB (Means: $(\mathrm{LB}=4.60) \approx(\mathrm{SB}=3.53)<(\mathrm{LA}=14.13)$ ), Figure 2A.

Cholestasis caused a statistically significant increase in NN both in animals administered WEB (Means: $(\mathrm{LB}=2.23)>(\mathrm{SB}=0.00))$ and those which were not (Means: $(\mathrm{LA}=9.73)>(\mathrm{SA}=0.00))$. WEB significantly reduced $\mathbf{F M}$ in animals with cholestasis (Means: $(\mathrm{LB}=2.23)<(\mathrm{LA}=9.73)$ ), Figure $2 \mathrm{~B}$.
Cholestasis caused a statistically significant increase in IF both in animals administered WEB (Means: $(\mathrm{LB}=1.10)>(\mathrm{SB}=0.00))$ and those which were not (Means: $(\mathrm{LA}=1.37)>(\mathrm{SA}=0.00))$. WEB significantly reduced IF in animals with cholestasis (Means: $(\mathrm{LB}=1.10)<(\mathrm{LA}=1.37)$ ), Figure $2 \mathrm{C}$.

Cholestasis caused a statistically significant increase in IDP both in animals to which WEB was administered (Means: $(\mathrm{LB}=1.27)>(\mathrm{SB}=0.00))$ and in those to which WEB was not administered (Means: $(\mathrm{LA}=1.37)>(\mathrm{SA}=0.00))$. WEB did not significantly reduce IDP in animals with cholestasis (Means: $(\mathrm{LA}=1.37)>(\mathrm{LB}=1.27)$ ) (Figure $2 \mathrm{D})$. 


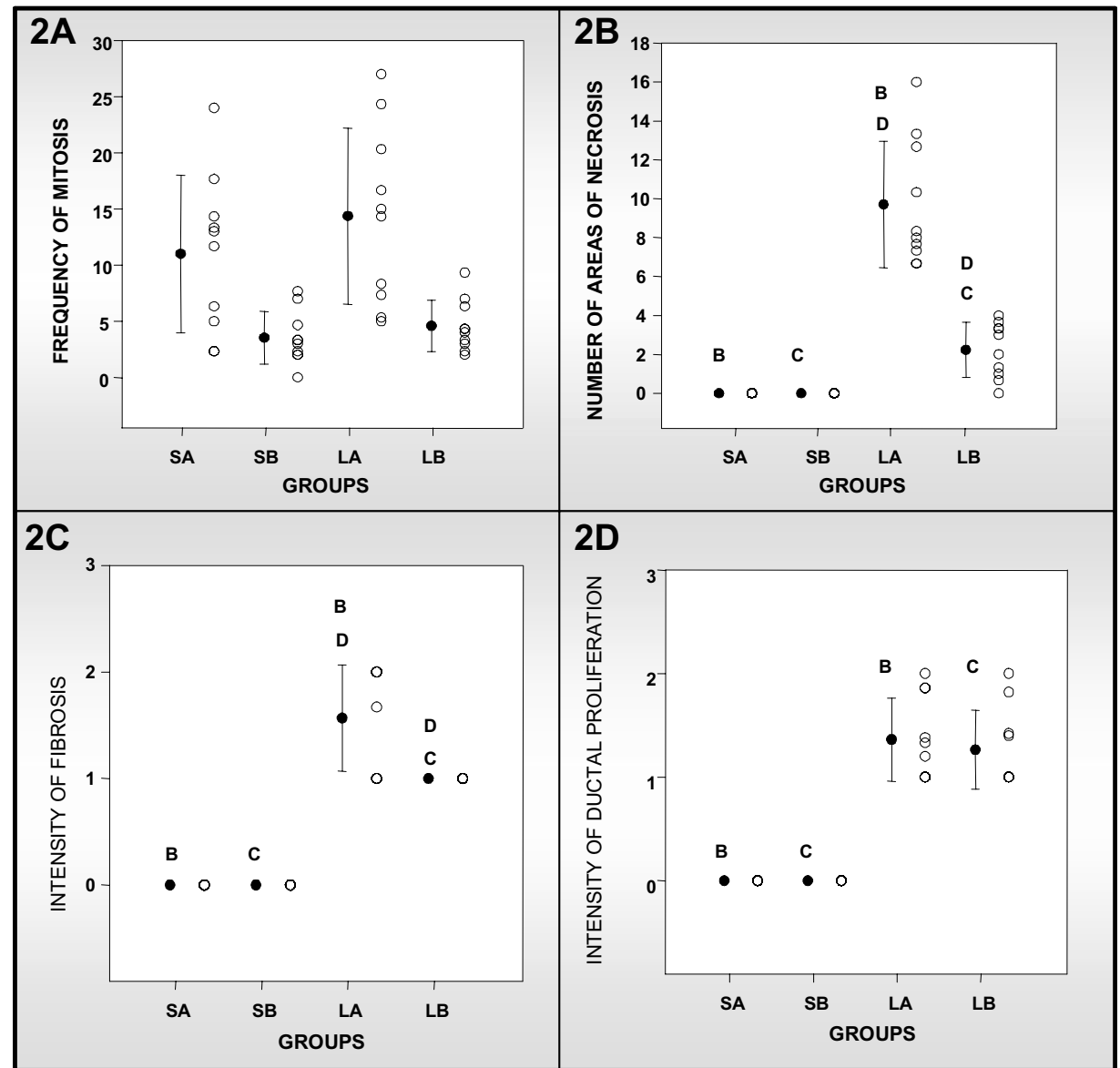

FIGURE 2 - Means ( of 30 readings - 3 per animal), standard deviations and individual values of histological lesions: Frequency of mitosis (2A), number of areas of necrosis (2B), Intensity of fibrosis (2C) and Intensity of ductal proliferation (2D) in rats, in groups of 10, submitted to one of the following treatments: SA: sham operation with daily administration of water; SB: sham operation with daily administration of WEB; LA: double ligature with common bile duct resection with daily administration of water; LB: double ligature with common bile duct resection with daily administration of WEB. Letters repeated in figures $2 \mathrm{~A}, 2 \mathrm{~B}, 2 \mathrm{C}$ and $2 \mathrm{D}$, of the graphs, indicate the group pairs with significant differences among them in the Wilcoxon test $(p<0,05)$ : $\mathbf{A}=\mathrm{SA}>\mathrm{SB}$; $\mathbf{B}=\mathrm{LA}>\mathrm{SA} ; \mathbf{C}=\mathrm{LB}>\mathrm{SB} ; \mathbf{D}=\mathrm{LA}>\mathrm{LB}$. cholestasis

Pearson's correlation between the groups with

In animals with cholestasis not receiving WEB (LA) there was a significant positive linear correlation between IDP and IF $\left(\mathrm{r}_{\mathrm{p}}=0.7852 ; \mathrm{p}=0.0071\right)$ and a significant negative lin- ear correlation between IDP and FM $\left(\mathrm{r}_{\mathrm{p}}=-0.8198 ; \mathrm{p}=0.0037\right)$, see Table 3 and Figure 3.

In animals with cholestasis with WEB administration (LB) there was a significant linear positive correlation between NN and IDP $\left(r_{p}=-0.8541 ; p=0.0017\right)$, see Table 4 and Figure 4 .

TABLE 3 - Pearson's correlations between pairs of histological variables in group LA

\begin{tabular}{|c|c|c|c|}
\hline Group LA & $\begin{array}{l}\text { Number of } \\
\text { areas of } \\
\text { necrosis }\end{array}$ & $\begin{array}{l}\text { Intensity of } \\
\text { fibrosis }\end{array}$ & $\begin{array}{l}\text { Intensity of ductal } \\
\text { proliferation }\end{array}$ \\
\hline Frequency of mitosis & $\begin{array}{l}c=0.3336 \\
p=0.3462\end{array}$ & $\begin{array}{c}c=-0.8198 \\
p=0.0037\end{array}$ & $\begin{array}{c}c=-0.7182 \\
p=0.0193\end{array}$ \\
\hline $\begin{array}{c}\text { Number of areas of } \\
\text { necrosis }\end{array}$ & ----------- & $\begin{array}{c}c=-0.5542 \\
p=0.0964\end{array}$ & $\begin{array}{c}c=-0.1932 \\
p=0.5927\end{array}$ \\
\hline Intensity of fibrosis & ----------- & ------------ & $\begin{array}{l}c=0.7852 \\
p=0.0071\end{array}$ \\
\hline
\end{tabular}

Shaded areas indicates a statistically significant linear correlation between pairs of variables $(\mathrm{p}<0.05)$. 
TABLE 4 - Pearson's correlation between pairs of histological variables in group LB

\begin{tabular}{|c|c|c|c|}
\hline Group LB & $\begin{array}{l}\text { Number of } \\
\text { areas of } \\
\text { necrosis }\end{array}$ & $\begin{array}{l}\text { Intensity of } \\
\text { fibrosis }\end{array}$ & $\begin{array}{l}\text { Intensity of ductal } \\
\text { proliferation }\end{array}$ \\
\hline Frequency of mitosis & $\begin{array}{l}r_{P}=0.2742 \\
p=0.4433\end{array}$ & $\bullet$ & $\begin{array}{c}r_{P}=-0.2264 \\
p=0.5293\end{array}$ \\
\hline $\begin{array}{c}\text { Number of areas of } \\
\text { necrosis }\end{array}$ & ------------ & $\bullet$ & $\begin{array}{c}r_{P}=-0.8541 \\
p=0.0017\end{array}$ \\
\hline
\end{tabular}

Shaded area indicate a statistically significant linear correlation between pairs of variables $(p<0.05)$

- The intensity of fibrosis of all animals was identical (1), thus correlation was impossible to perform.

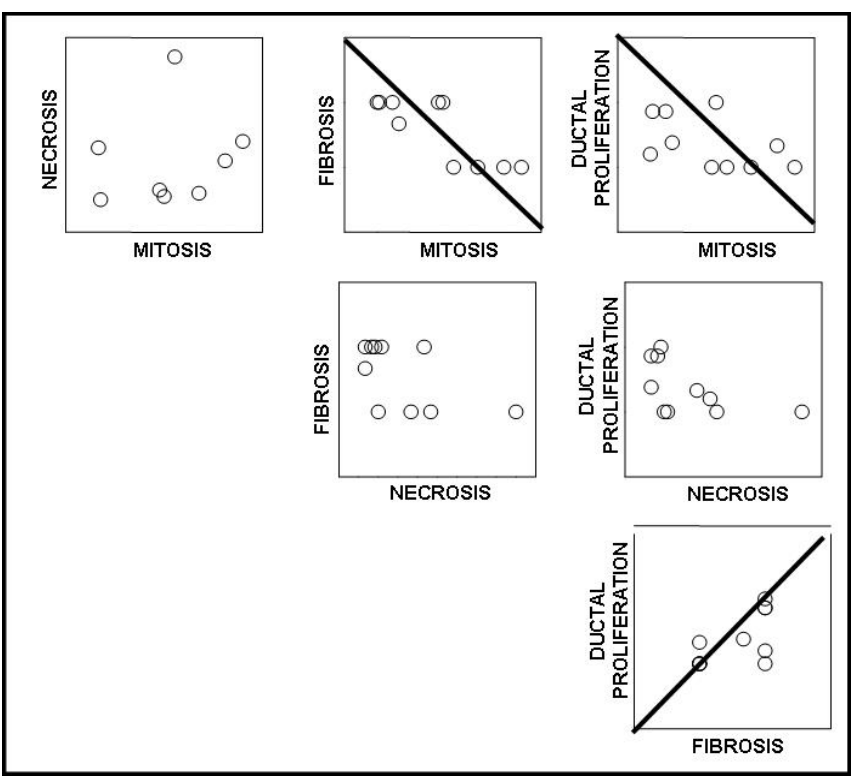

FIGURE 3 - Histological variables in group LA (ligature of the common bile duct with administration of distilled water) Graphs of dispersion showing the results of analysis of Pearson's linear correlation

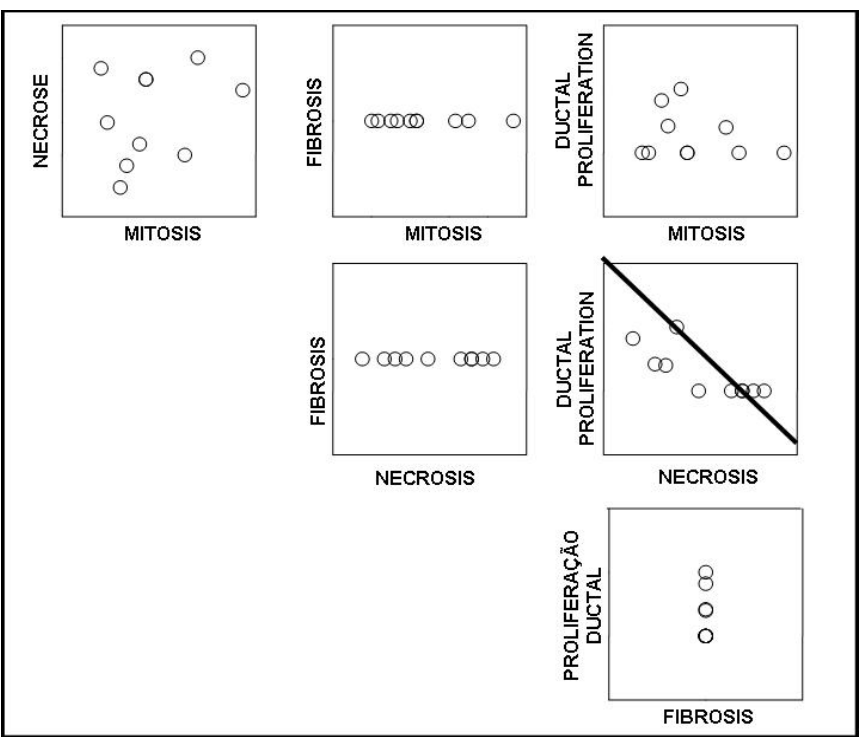

FIGURE 4 - Histological variables in group LB (ligature of the common bile duct with administration of WEB). Graphs of dispersion showing the results of analysis of Pearson's linear correlation

\section{Discussion \\ Effects of cholestasis}

In order to characterize the effects of cholestasis after ligature and resection of the common bile duct (LRBD) we summarized the following alterations: an increase in the aminotransferase serum activities (AST and ALT), a prolongation of sleeping time after pentobarbitol, an increase in liver wet weight and the presence of the following histological lesions - necrosis, fibrosis, ductal proliferation and an increase in the number of hepatocyte mitoses.

The sleeping time test induced by pentobarbitol, in hypnotic doses, was proposed as a simple, non-invasive test of liver function in rats. It reflects the velocity of pentobarbitol disintoxication by the hepatocyte cytochromes P- $450^{10}$. The hepatocytic lesion in cholestasis induced by LRBD leads to a reduction in the isoenzymes of the cytochrome P- $450^{11}$. The sleeping time test induced by pentobarbitol, has been used to evaluate liver function in several experimental models: biliary cirrhosis secondary to extra-hepatic biliary obstruction ${ }^{30,31}$ and by carbon tetrachloride ${ }^{13,14,15,32,33}$. In the literature we found no reports on sleeping time in young rats with obstructive cholestasis by LRBD.

The aminotransferase serum activities (AST and ALT) are indicators of the velocity of hepatocellular damage and have been applied in the study of several experimental models for hepatopathies ${ }^{34,8}$. Our results are in agreement with other findings in the literature: experimental cholestasis by anaphthylisothiolcyanate - ANIT $^{34,35}$, experimental cholestasis by LRBD in adult rats ${ }^{36,37,9,8}$, cholestasis induced by endotoxins $^{38}$ and cholestasis associated with total experimental parenteral nutrition in adult rats ${ }^{39}$. In the literature we found no reports on aminotransferase serum activities (AST and ALT) in young rats with obstructive cholestasis by LRBD.

Hepatomegaly is an important clinical characteristic in cholestasis. The liver weight increases as a result of the depositing of conjunctive tissue, the formation of regenerative nodules and ductal proliferation ${ }^{40}$. Our results are in agreement with the findings of Aller et al, $1993^{41}$ and Sokal et al., 1996 $6^{42}$, who studied rats submitted to LRBD, and who also observed an increase in liver weight in these animals. 
The presence of necrosis ${ }^{8}$, hepatic fibrosis ${ }^{40,9,8}$ and ductal proliferation ${ }^{21,8}$ in the biliary cirrhosis secondary to ligature of the common bile duct model has been confirmed in recent works. As our study has pointed out, Aggerbeck et al., 1983 ${ }^{22}$, studying the model of cholestasis by LRBD in adult rats also observed an increase in the number of mitoses in cholestatic animals.

In animals with cholestasis without the administration of WEB there was a positive correlation between the intensity of the fibrosis and the intensity of the ductal proliferation. This correlation is to be expected, as in this experimental model these two lesions are intensely related to each other ${ }^{21}$.

The frequency of mitosis presented negative correlation with both intensity of fibrosis and ductal proliferation. Perhaps this correlation can be explained by the deviation of oval cell (originated from stem cells) transformation into cholangiocytes, diminishing the oval cell transformation into hepatocytes. Although it is known that oval cells are totipotent, in that they can transform themselves into either cholangiocytes or hepatocytes ${ }^{43,44,45}$, there is no evidence in the literature that the transformation into in cholangiocytes diminishes the transformation into hepatocytes, which our study suggestswith the possibility of totipotent oval cells.

\section{WEB effects in the absence of cholestasis}

The administration of WEB in animals without choletasis resulted in a shorter sleeping time, which is in agreement with the work of Fischman et al., 1991 ${ }^{46}$, who studied the effects of water extract of Coleus barbatus in adult rats, concluding that the animals which received the extract presented a 20 to $25 \%$ reduction in sleeping time induced by pentobarbitol. Therefore, WEB must have a stimulatory effect on the cytochrome P450. No reports on the effects of WEB on the cytochrome $\mathrm{P} 450$ were found in the literature.

WEB also reduced the number of mitoses in the absence of cholestasis. No reports on the effects of WEB and a reduction in the number of mitoses were found in the literature.

\section{WEB effectsf on cholestasis}

We were able to show that WEB, at the dosage applied, in biliary cirrhosis secondary to extra-hepatic biliary obstruction in young rats has a hepatoprotective effect characterized by the following actions: it diminished the increase in aminotransferase serum activities (ALT and AST); shortened sleeping time induced by pentobarbitol; prevented the increase in liver wet weight; reduced the number of necrotic areas, the intensity of hepatic fibrosis and hepatocytic regeneration (measured by the number of mitoses).

This hepatoprotective action may be mediated by forskolin, which is one of the most important components of Coleus barbatus ${ }^{5}$. Forskolin stimulates adenylate cyclase and the production of the secondary messenger $\mathrm{AMP}^{47}$, which has a hepatoprotective action against glycochenodeoxycholic acid in hepatocyte cultures ${ }^{48}$. The accumulation of this acid appears to be the most significant factor in the hepatocytic damage of cholestasis. We were unable to show the effect of WEB on ductal proliferation, perhaps due to the small sample size.

The effect of WEB on the reduction of the frequency of mitoses in animals with cholestasis suggests a reduction in the hepatocytic regeneration, which is in agreement with the reduced intensity of necrosis. No reports were found in the literature on the use of WEB in the reduction in the number of mitosis in cholestasis.

Although the group with cholestasis with WEB administration did not present a greater ductal proliferation than the group with cholestasis with distilled water administration, there was a negative correlation between ductal proliferation and the number of necrotic areas. This negative correlation could indicate that one process inhibits the other, which is not the case, or that a third factor inhibits one and stimulates the other, which suggests that the WEB, possibly through the action of forskolin, inhibits necrosis and stimulates ductal proliferation, as show above.

We present this hypothesis even though it was not possible to demonstrate any difference between the ductal proliferation with or without the administration of WEB, perhaps due to the sample size. Knowing that forskolin stimulates ductal proliferation in the presence of the reduction of vagal tonus ${ }^{49}$, further studies should be conducted to test for the existence of vagal hypotonia in this cholestasis model and if found not to be the case, if this action also occurs in the presence of normal vagus tonus.

\section{Conclusions}

The administration of water extract of Coleus barbatus exerts an effect on animals without cholestasis (sham surgery) reducing the frequency of mitoses and the sleeping time induced by pentobarbitol. In choestasis, the water extract of $\mathrm{Co}$ leus barbatus exerts a hepatoprotective effect, demonstrated by the reduction of: the sleeping time with pentobarbitol, aminotransferase seric activity of AST and ALT, liver wet weight, hepatocytic regeneration (measured by the number of mitoses), the number of necrotic areas, the intensity of fibrosis and, further, by the negative correlation between the number of necrotic areas and the intensity of ductal proliferation.

\section{References}

1. Otte JB. History of pediatric liver transplantation. Where are we coming from? Where do we stand? Pediatr Transplant. 2002;6:378-87.

2. Weisdorf SA, Hamel N, Pierpont ME, Bowers LD, Cerra FB. Increased dietary branched-chain amino acids do not improve growth in developing rats with chronic biliary obstruction. J Nutr. 1991;121:1447-53.

3. Medeiros MV, Freitas LA, Andrade ZA.Differences in hepatic pathology resulting from bile duct obstruction in young and old rats. Braz J Med Biol Res. 1988;21:75-83.

4. Teske M, Trentini MM. Herbarium. Compêndio de Fitoterapia. 3ed. Ed. Herbarium. 1997. p.60-2.

5. Valdes LJ, Mislankar SG, Paul AG. Coleus barbatus (C. 
forskohlii) (Lamiaceae) and the potencial new drug Forskolin (Colenol). Econ Botany. 1987;41:474-83.

6. Dubey MP, Srimal RC, Nityanand S, Dhawan BN. Pharmacological studies on coleonol, a hypotensive diterpene from Coleus forskohlii. J Ethnopharmacol. 1981;3:1-13.

7. Oh SH, Nan JX, Sohn DW, Kim YC, Lee BH. Salvia miltiorrhiza inhibits biliary obstruction-induced hepatocyte apoptosis by cytoplasmic sequestration of p53. Toxicol Appl Pharmacol. 2002;182:27-33.

8. Zhong Z, Froh M, Lehnert M, Schoonhoven R, Yang L, Lind H, Lemasters JJ, Thurman RG. Polyphenols from Camellia sinenesis attenuate experimental cholestasis-induced liver fibrosis in rats. Am J Physiol Gastrointest Liver Physiol. 2003;285:1004-13.

9. Park PH, Nan JX, Park EJ, Kang HC, Kim JY, Ko G, Sohn $\mathrm{DH}$. Effect of tetrandrine on experimental hepatic fibrosis induced by bile duct ligation and scission in rats. Pharmacol Toxicol. 2000;87:261-8.

10. Lutz J, Vagner M. Recovery from pentobarbital-induced sleed after administration of perfluorinated blood substitutes. Artif Organs. 1984;8:41-3.

11. Tateishi T, Watanabe M, Nakura H, Tanaka M, Kumai T, Kobayashi S. Liver damage induced by bile duct ligation affects CYP isoenzymes differently in rats Pharmacol Toxicol. 1998;82:89-92.

12. Basu, AT. Hepatoprotective effects of Calotropis procera root extract on experimental liver damage in animals. Fitoterapia. 1992;63:507-14.

13. Gilani AH, Janbaz KH. Hepatoprotective effects of Artemisia acoparia against carbon tetrachloride: an environmental contaminant. J Park Med Assoc. 1994;44:65-8.

14. Gilani AH, Janbaz KH. Studies on protective of Cyperus scariosus extract on acetaminiphen and CCl4- induced hepatotoxicity. Gen Pharmacol. 1995;26:627-31.

15. Gilani AH, Janbaz KH, Shah BH. Esculetin prevents liver damage induced by paracetamol and CCl4. Pharmacol Res. 1998; 37:31-5.

16. Dufour DR, Lott JA, Nolte FS, Gretch DR, Koff RS, Seeff LB. Diagnosis and monitoring of hepatic injury. I performance characteristics of laboratory tests. Clinical Chem. 2000;46:202749.

17. Fujii T. Toxicological correlation between changes in blood biochemical parameters and liver histopathological findings. J Toxicol Sci. 1997;22:161-83.

18. Trams EG, Symons AM. Morphological and functional changes in the livers of rats after ligation or excision of the common bile duct. Am J Pathol. 1957;33:13-25.

19. Li MK, Crawford JM. The pathology of cholestasis. Semin Liver Dis. 2004;24:21-42.

20. Jaeschke H, Gujral JS, Bajt ML. Apoptosis and necrosis in liver disease. Liver Int. 2004;24:85-9.

21. .Pinzani M, Milani S. Cholestasis and fibrosis. In: Manns MP, Boyer JL, Janses, PLM, Reichem J. (Eds). Cholestatic liver diseases. Dordrecht: Kluwer Academic Publishers; 1998. p.8899.

22. Medeiros MV, Freitas LA, Andrade ZA.Differences in hepatic pathology resulting from bile duct obstruction in young and old rats. Braz J Med Biol Res. 1988;21:75-83.

23. Aggerbeck M, Ferry N, Zafrani ES, Billon MC, Barouki R, Hanoune J. Adrenergic regulation of glycogenolysis in rat liver after cholestasis. Modulation of the balance between alpha 1 and beta 2 receptors. J Clin Invest. 1983;71:476-86.

24. Comissão de Ensino do Colégio Brasileiro de Experimentação Animal (COBEA) - Manual para técnica em bioterismo; 1996.

25. Canadian Council of Animal Care. Guide do the Care and Use of Experimental Animals. v.1 and 2. Ottawa, Ontario: Canadian Council on Animal Care; 1980-1984.

26. Lajolo FM, Campos França MH, Zucas SM. Importância da cor da ração no consumo da mesma por ratos (Ratus norvegicus var albinus). Rev Fac Farm Bioquim. 1969;7:95103.

27. Fox MRS, Briggs, GM. Salt mixtures for purified type diets III - Na improved salt mixtures for chicks. J Nutr. 1960;72:24250 .

28. Cameron GR, Oakley CL. Ligation of the common bile duct. J Pathol Bacteriol. 1932;35:769-99.

29. Battochio APR, Santos AG, Silva CRM, Santos AR, Coelho CAR. Adaptação do modelo experimental de colestase extrahepática em ratos jovens. Acta Cir Bras. 2004;19(1):70-3.

30. Knodell RG, Brooks DA, Allen RC, Kyner WT. Alterations in pentobarbital and meperidine pharmacokinetics induced by bile duct ligation in the rat. J Pharmacol Exp Ther. 1980;215:619-25.

31. Lee SS, Girod C, Braillon A, Hadengue A, Lebrec D Hemodynamic characterization of chronic bile duct-ligated rats: effect of pentobarbital sodium. Am J Physiol. 1986;251:G17680 .

32. Lutz J, Krafft MP. Longitudinal studies on the interaction of perfluorochemicals with liver cytochromes P-450 by means of testing the rate of detoxification of pentobarbital. Adv Exp Med Biol. 1997;411:391-4.

33. Janbaz KH, Gilani AH. Studies on preventive and curative effects of berberine on chemical-induced hepatotoxicity in rodents. Fitoterapia. 2000;71:25-33.

34. Neghab M, Stacey NH. Alpha-naphthylisothiocyanate-induced elevation of serum bile acids: lack of causative effect on bile acid transport. Chem Biol Interact.1996;99:179-92.

35. Kongo M, Ohta Y, Nishida K, Sasaki E, Harada N, Ishiguro I. An association between lipid peroxidation and alphanaphthylisothiocyanate-induced liver injury in rats. Toxicol Lett. 1999;105:103-10.

36. Castro e Silva O Jr, Barbosa AB Jr, Picinato MANC, Franco CFF, Viaro F, Souza MEJ. Intumescimento osmótico mitocondrial passivo do fígado na colestase extra hepática aguda. Acta Cir Bras. 1997; 12:13-5.

37. Dempsey A.M, Franco CFF, Picinato MANC, Souza MEJ, Jordani MC, Castro e Silva OJ. função mitocondrial hepática compensatória na colestase extra hepática aguda. Acta Cir Bras. 2000;15:76-7.

38. Lechner AJ, Velasquez A, Knudsen KR, Johanns CA, Tracy TF Jr, Matuschak GM.Cholestatic liver injury increases circulating TNF-alpha and IL-6 and mortality after Escherichia coli endotoxemia. Am J Respir Crit Care Med. 1998;157:1550-8. 
39. Zahavi I, Rosezki O, Stolkarts Y, Shamir R, Heckelman B, Marcus H, Dinari G. The effect of cisapride on total parenteral nutrition-associated cholestasis in rats. Isr Med Assoc J. 2000;2:91-3.

40. Wasser S, Tan CE. Experimental models of hepatic fibrosis in the rat. Ann Acad Med Singapore. 1999;28:109-11.

41. Aller MA, Lorente L, Alonso S, Arias J. A model of cholestasis in the rat, using a microsurgical technique. Gastroenterology. 1993;28:10-4.

42. Sokal EM, Baudoux MC, Collette E, Hausleithner V, Lambotte L, Buts JP. Branched chain amino acids improve body composition and nitrogen balance in a rat model of extra hepatic biliary atresia. Pediatr Res. 1996;40:66-71.

43. Alpini G, Ulrich C, Roberts S, Phillips JO, Ueno Y, Podila PV, Colegio O, LeSage GD, Miller LJ, LaRusso NF. Molecular and functional heterogeneity of cholangiocytes from rat liver after bile duct ligation. Am J Physiol. 1997;272:G289-97.

44. Lenzi R, Liu MH, Tarsetti F, Slott PA, Alpini G, Zhai WR, Paronetto F, Lenzen R, Tavoloni N.Histogenesis of bile duct- like cells proliferating during ethionine hepatocarcinogenesis: evidence for a biliary epithelial nature of oval cells. Lab Invest. 1992;66:390-402.

45. LeSage G, Glaser S, Alpini G.Regulation of cholangiocyte proliferation. Liver. 2001;21:73-80.

46. Fischamn, LA, Skorupa LA, Souccar C, Lapa AJ. The water extract of Coleus barbatus benth decreases gastric secretion in rats. Mem Inst Oswaldo Cruz. 1991;86:141-3.

47. Seamon KB, Padgett W, Daly JW.Forskolin: unique diterpene activator of adenylate cyclase in membranes and in intact cells. Proc Natl Acad Sci USA. 1981;78:3363-7.

48. Webster R, Anwer MS. Cyclic adenosine monophosphatemediated protection against bile acid-induced apoptosis in cultured rat hepatocytes. Hepatology. 1998;27:1324-31.

49. Barron HV, Alam I, Lesh MD, Strunk A, Bass NM. Autonomic nervous system tone measured by baroreflex sensitivity is depressed in patients with end-stage liver disease. Am J Gastroenterol. 1999;94:986-9.

\section{Correspondence:}

Ana Paula Ronquesel Battochio

Rua da Alegria 329 - Recanto Azul

18603-090 Botucatu - SP Brazil

Phone: (55 14)9123-9276

Fax: (55 14)3811-6274

apbattochio@ig.com.br
Conflict of interest: none Financial source: National Counsel for Scientific and Technological Development (CNPq). Process no 140556/02-8

Received: November 23, 2007

Review: January 15, 2008

Accepted: February 12, 2008

\section{How to cite this article}

Battochio APR, Coelho KLR, Sartori MS, Coelho CAR. Hepatoprotective effect of water soluble extract of Coleus barbatus in cholestasis in young rats. Acta Cir Bras. [serial on the Internet] 2008 May-June;23(3).

Available from URL: http://www.scielo.br/acb 